\title{
CONTROLLING URBAN SOCIETY DURING WORLD WAR I: COOPERATION BETWEEN BELGIAN AUTHORITIES AND THE FORCES OF
MILITARY OCCUPATION
}

Benoit Majerus

G

reater metropolitan Brussels was by far the largest urban area occupied by the German army during the First World War. ${ }^{1}$ The areas that the Germans called "Greater Brussels" during the war comprised sixteen independent communes. ${ }^{2}$ Their aggregate population in 1914 was 700,000 . The Germans refused, however, to take this diversity into account and instead treated the city of Brussels as a single administrative unit. Using the problem of "policing" as a guide, this essay will examine both the existing and newly established agencies that maintained order during the four years of the conflict; in the same connection, it will also analyze the cooperation between Belgian local authorities and the German army.

When the Fourth Corps of the German army entered Brussels, the behavior of occupying forces was regulated by a basic text of international law. Both Belgium and Germany had signed the "Convention on the Laws and Customs of Land War" at the Hague on October 18, 1907. Article III of this documen was devoted to the problem of "military authority in enemy territory." While

The only recent comprehensive account of Belgium during the First World War is Sophie de Schaepdrijver, De Groote Oorlog: Het koninkrijk Belgie tijdens de Eerste Wereldoorlog (Amsterdam, '1997).

${ }_{2}^{2}$ These were Anderlecht, Auderghem, Brussels, Etterbeek, Forest Ixelles, Jette-SaintPierre, Koekelberg, Laeken, Molenbeek-Saint-Jean, Saint-Gilles, Saint-Josse-ten-Noode Schaerbeek, Uccle, Watermael-Boitsfort, and Woluwe-Saint-Lambert. See Un souvenir historique: Les avis, proclamations et nouvelles de guerre allemands affichés a Bruxelles pen dant l'occupation (18 vols., Brussels, n.d.), 1, First Supplement: 6-7. 
the rights and obligations of the occupying force were thus inscribed into a normative body of law, the convention was silent about the behavior of those who lived in the occupied territory, specifically about conduct of indigenous institutions of public administration in this territory. To the occupying force, however, it granted the authority to promulgate laws, which implicitly obligated those in these areas at least to recognize the realities of the new situation. This consideration appears to have motivated officials in several Belgian ministries, who decided in September 1914, on the basis of the Hague Convention, to remain at their posts. ${ }^{3}$ They included officials in the ministries of the interior, public works, agriculture, justice, culture, research, and finances, who continued to work under their respective secretaries-general. ${ }^{4}$

The Belgian law of August 4, 1914, which regulated the delegation of powers in case of invasion, was no more explicit on this question. It allowed provincial councils and permanent provincial deputations, as well as communal councils, to pass certain laws without the approval of the governor of the province or the king. ${ }^{5}$ The law-makers seem to have assumed that these institutions would not only survive an invasion of the country, but would also con tinue to exercise power under the occupation regime. The contacts between Belgian administrative agencies and the occupier were not, however, explicitly addressed.

In a circular to communal authorities on August 4,1914, Paul Berryer, the Belgian Minister of the Interior, did address the problem. The first part of his circular analyzed the wartime situation prior to occupation. Insofar as communa authorities were distinguished from political functionaries, they were obligated to remain in office, unlike other public agencies, which were permitted to resign In case of occupation, the document continued, officials of the Belgian state

may fulfill their missions only to the extent that a foreign authority does not prevent them from doing so. But local authorities must remain in office and continue to administer the commune.... Communal authorities will thus necessarily be in daily contact with foreign authorities. Because these authorities will have power, they will be obligated respon sibly to take all measures to assure public life and order... The mayor will attend with particular care to the maintenance of order and security within his jurisdiction. If it should be necessary, he will ask the forrign authorities to aid him. ${ }^{\circ}$

${ }^{3}$ Louis Gille, et al., Cinquante mois d'occupation allemande (4 vols., Brussels, 1919) 1:75-77.

${ }^{4}$ See André Hardewyn, "Een 'vergeten' generale repetitie: De Duitse oorlogsbelastingen tijdens de Eerste Wereldoorlog," Cahiers d'histoire du temps présent 6 (1999) 183-210; Hommage jubilaire à M. l'Echevin Steens a l'occasion du cinquantieme anniversaire de son entrée au conseil communal (Brussels, 1932), 20; Jean Levie, Michel Levie (1851-1939) et le mouvement chretien social de son temps (Louvain, 1962), 430-45.

${ }^{5}$ Moniteur Belge (Brussels, 1914), 5000-5001.

- Archives de la Ville de Bruxelles (hereafter cited AVB), Pol 14-18, Circulaire du 4 août rédigée par Paul Berryer.
The circular thus left no doubt about the attitude to be adopted by an occupied commune. It was a question of maintaining public life at the local level a general strike, which would force the occupier to put a complete administrative system in place, was ruled out. As long as it did not call the Belgian "legal government" into question, cooperation with the occupying power was even held to be desirable. What would the tenor of this document have been had the minister foreseen more than four years of occupation? The spirit of the circular seems to have addressed only a short war, during which the preservation of administrative structures was deemed essential in order to permit the smooth resumption of affairs after liberation in the not-too-distant future.

Whatever Berryer's intent, the situation that he addressed hypothetically on August 4 became reality on August 20 . On the day before, the German general Karl von Bülow called on the municipal authorities to present themselves at the city gates on the 20th, so they might be "provisionally retained" with an eye to avoiding popular unrest. ${ }^{7}$ After a meeting with a delegation led by the mayor, Adolphe Max, the Germans agreed to drop the question of hostages. At the request of Kriegsheim, the head of the German delegation, that he continue to ensure the functioning of the city council (college des bourgmestre et échevins), Max declared that "the authorities would do everything in their power to ensure the security of German troops who were marching through or were stationed in Brussels." ${ }^{8}$ This response suited both parties, for the German military authorities were in no position to install an elaborate administrative regime of their own in Brussels. The agreement was ratified by the new German gov ernor on September 2,1914. In a public announcement, he specifically invited both national and local officials to continue at their posts. For his part, Max was now in a position to protect his control over his own bureaucracy and to hope to play a significant role afterwards. The same day, however, General Jakobsky, who negotiated the capitulation of Brussels, submitted a contract that stipulated that Max would perform his functions under the authority of the German military government in the city. Max refused to sign. ${ }^{9}$

In subsequent negotiations between the Germans and the municipal authorities, the question of paralysis in the local administration regularly surfaced. Thus when the city council heard of Max's arrest from the military governor, Walther von Lüttwitz, it at first refused to remain in session. Lüttwitz thereupon threatened to name a German mayor, to put the army in charge of the police, to quarter German troops with civilian residents, and to install artillery around the city. The members of the council thereupon backed down and agreed to

${ }^{7}$ See John Horne and Alan Kramer, German Atrocities, 1914: A History of Denial (London, 2001), 18, 23.

${ }_{8}$ Auguste Vierset, Mes souvenirs sur l'occupation allemande en Belgique (Paris, 1933) 58-61; Gille, Cinquante mois, 1:6-10.

${ }^{9}$ Lucien Cooremans and Mina Martens, Adolphe Max (Brussels, 1964), 96-97. 
keep running the administration. What was the reality behind these German threats? The last one was already a feature of occupation. The naming of a German mayor would probably have provoked a strike among communal officials. At that moment, however, as it marched toward the English Channel, the German army could not afford significant difficulties to its rear. It was also unlikely that a sufficient number of soldiers could have been detached from the forward units to take over police functions in the city. Nevertheless, the council chose not to provoke a crisis. Moreover, Max himself asked its members to remain in their positions..$^{10}$ Like its counterparts in the suburbs, the communal administration of Brussels thus continued to function throughout the war. The tensions among them--and between them and the Germans-were many during the next four years, but they never really cast doubt on the principle that communal authorities should have a presence. A Hungarian journalist described the distribution of institutional power in this way: "All that belonged to the Belgian State is now German, but everything connected with municipal affairs can remain Belgian." ${ }^{11}$

The Germans had no concrete plans for the occupation of Belgium. Unlike what happened twenty-five years later, when the German army prepared the occupation well in advance, the situation in August 1914 was characterized by considerable chaos. In the end, the Germans' approach to an occupation regime in 1914 rested on their experiences during the war against France in 1870, when they had set up so-called governments-general in Alsace-Lorraine, Reims, and at Versailles. Accordingly, most of Belgium was subordinated to the rule of a governor-general (Generalgouverneur), a soldier who was appointed by the Kaiser and ruled subject to his approval alone. ${ }^{12}$ In the management of civilian affairs, he was assisted by a Verwaltungschef, who was the leader of a Zivilverwaltung, or civilian administration, which was formally subordinated to him. In the first instance, this administration oversaw the Belgian ministries that continued to operate. The same structure-a military head assisted by a civilian administrator-was then replicated at the regional and local levels.

The military governors were responsible for maintaining public order, the heads of the civilian administration for restarting the Belgian economy. In the summer of 1917 the Zivilverwaltung, whose chief at the time was Maximilian von Sandt, the former Regierungspräsident of Aachen, was divided into the two administrative regions, which remained in place for the rest of the war. One

10 Vierset, Mes Souvenirs, 134

'Odon Halasi, Belgium under the German Heel (London, 1917), 110.

${ }^{12}$ Ludwig von Köhler, Die Staatsverualtung der besetzten Gebiete: Belgien (Stuttgart and New Haven, 1927). Three governors served during the war: Colmar von der Goltz (from August 26 to December 2, 1914), Moritz von Bissing (from December 2,1914 to April 18, 1917), and Ludwig von Falkenhausen (from May 3, 1917 until the end of the war). of these had jurisdiction in Flanders, at the head of which was placed Alexander Schaible; the other, which was directed by Karl Haniel, covered Wallonia. ${ }^{13}$

The German authorities also installed three police agencies to maintain order in Brussels. The military police (Militärpolizei) were the first to arrive. They were responsible to the governor-general and were composed of reserve troops from the Landwehr and Landsturm. As their name suggested, the military police were initially responsible for supervising German soldiers in Belgium. The number of these troops stationed in Greater Brussels alone was estimated to be between eight and ten thousand; in August 1916 there were some twenty-one thousand within the province of Brabant. ${ }^{14}$ These soldiers were joined by the many troops who passed through the Belgian capital or were stationed there for a day or two.

Beyond this traditional role, the jurisdiction of the military police extended to broader tasks of maintaining order in the occupied territories. During the four years of occupation, they played an important role in controlling the local population. It is difficult to determine the exact functions of the military police. Most of these units were drawn from the Prussian army or were set up in Belgium by the governor-general himself. In 1917 around 780 soldiers were employed in the ten units that made up the military police in Greater Brussels; in cases of emergency the number rose to a thousand. Seven hundred additional soldiers, who were less visible, protected the rail lines. ${ }^{15}$ Because it was the only German agency with a substantial number of troops available, the occupying authorities counted on the military police in case of trouble in the city.

In Imperial Germany the deportment of the army in urban areas had been the object of much debate. One of the participants in these debates, Moritz von Bissing, the future governor-general in Belgium, had taken a stand on the question. "Nothing is more dangerous than tentative measures," he wrote. "Delay subverts the spirit of even the best troops, while attack and engagement strengthens their morale." ${ }^{16}$ During the war, police units were massively deployed in the city whenever the Germans had reason to expect trouble. During the second half of the war, as the occupiers came increasingly to fear a strike by municipal officials, they worked out a detailed emergency plan for much more systematic military control of the city.

13 Paul Oszwald, "Errichtung des deutschen Generalgouvernements in Belgien," Staat und Gesellschaft: Erich Brandenburg zum 60. Geburtstag (Leipzig, 1928), 234-69.

${ }_{14}$ Bayerisches Hauptstaatsarchiv (hereafter cited (BayStA), Handschriften-Samlung Hurt (HS-2261), Halbjahresbericht für die Zeit vom 1. Februar bis 31. Juli 1917: Gouvemement von Brüssel und Brabant.

15 BayHStA, HS-2261, Übersicht vom 31. Juli 1917: Tägliche Verwendung der Unteroffiziere und Mannschaften der unterstellten Truppenteile der Kommandantur

Brüssel.

${ }^{16}$ Bernd Ulrich, Jakob Vogel, and Benjamin Ziemann, Untertan in Uniform. Militar und Militarismus im Kaiserreich 1871-1914 (Frankfurt a.M., 2001), 164. 
While the military police quickly became an everyday reality, the political We object of a myth, the symbol of German arbitrariness. At the of 1914 and the beginning of 1915, the units of the preexisting Belgian the of 1914 and the beginis political police were consolidated and placed under the command of a central headquarters, the Zentralpolizeistelle, in Brussels. The resulting policical police consisted of both soldiers and civilians. The seven provinces that made up the government-general were divided into five police divisions and fifeen sections. Division V, for example, covered Brabant and comprised two districts in Brussels and one in Louvain. One of the two districts in Brussels dealt with espionage, the other with the clandestine press. ${ }^{17}$ In July 1917 the political police counted the 172 officials. ${ }^{18}$ Their effectiveness did not, however, lie in their numbers, nor in the Belgians who worked for the police and to the denunciations that represented a principal asset.

At the same time as the Zentralpolizeistelle was set up, the occupiers creAt the same time as the Confronted by an ated an office of Sittenpolizei, or morals police, in Brussels. Confronted by an explosion in the number of prostitutes, the Germans resorted to a policy of stric regulation, which was calculated to reduce the risk of venereal disease. With regulation, which was calice in eleven agents, the German morals police in greater metropolitan Brussels disregarded communal boundaries and directed a team of local policemen. In the following months a similar apparatus was put in place in other Belgian cities.

After the departure of the Belgian national army and the gendarmerie, only the communal police remained to protect public order. These local forces were directed by the mayors of each commune. Before the war the police had been directed by the mar, Max con vinced the Belgian Minister of War, Charles de Broqueville, not to incorporate the local police into the army, but owing to failures of communication, thi information arrived late among some units of the Belgian army. In the end 299 policemen departed from Brussels for the front. They represented almost forty percent of the prewar complement. The ratio fell to three hundred policemen fur a hundred thousand inhabitants-roughly what it had been in 1900 . me police uniformly, however. A large majority of

17 Archives Générales du Royaume (hereafter cited AGR), Service des prisons/bureau Illemand de la prison de Saint-Gilles (T-465).

18 Ber de la prison de Sereich der

${ }_{18}$ Bundesarchiv-Berlin (BarchB), R1501-19374, Nachweisung der Dienststellen und Zentralpolizeistelle des General-Gouverneurs in Belgien vorhandenen Dienststellen und der bei diesem beschäftigten Militär- und Zivilbeamten; BarchB, R1505-19455, Verwaltungsbericht des Verwaltungschefs für Flandern für das Halbjahr August 1917 bis Januar 1918 .

19 Benôt Majerus, "La prostitution à Bruxelles pendant la Grande Guerre: Contrôle et pratique," Crime, History, and Societies 7 (2003): 5-42.

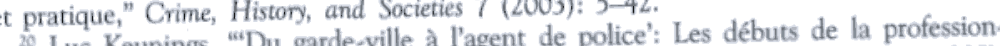
(Brussels, 1988) $1-87$ those who were mobilized were lower-level policemen. Of the 523 on the force on the eve of the war, 279 were called to the colors. The policemen who made up the basis of the apparatus were thus reduced by more than a half; their daily presence on the street had ensured close control of the population and urban space. Although the figures are not as precise as they are for Brussels, other communal police forces appear to have been affected in similar ways, whether because of mobilization or other dislocations. ${ }^{21}$ In March 1917 the police force in Brussels counted 652 officers, but they now included auxiliary policemen who had no regular status, as standards of admission were relaxed. "A. E.," for example, had been declared medically unfit for military service and had been unable to go on patrols, but he remained on the force because of a shortage of manpower. Training was reduced from six to three weeks. ${ }^{22}$

Apart from hiring new personnel, which was difficult in any case because so many potential candidates were at the front, the local authorities revived the old idea of a force composed of the city's citizens. In a country like Belgium, where the autonomy of local government had been regarded as a pillar of democracy, the idea of a civilian police force found a considerable echo after Max introduced it on August 9, 1914. The mission of this force was to "guarantee order and security in the capital, in cooperation with other forces at the disposal of the authorities." ${ }^{23}$ All men between the ages of twenty-five and fifty were required to serve; they were divided into fifteen stations around the city. However, problems quickly arose. Changing the name of the force to "civil guard" in February 1915 suggested that service was to become voluntary. The force was plagued by indiscipline and a pronounced "combativeness" toward German soldiers. It was animated more by patriotism than professional training. Cooperation with the occupier, which the regular metropolitan police regarded as unavoidable, was more difficult for the civil guard. In the end, the force was abolished. As a counterpart to this organization, which had been recruited largely from the middle classes, the metropolitan authorities also created a proletarian guard. This step had two immediate consequences. More than a hundred workers, many of whom had been unemployed, found work. In addition, two stations of the proletarian guard were established in quarters of the city that were inhabited by the "dangerous classes"-in the rue de Schaerbeek and the rue Joseph Stevens. In this way, a system of self-regulation emerged, as workers controlled other workers.

The German and Belgian authorities alike had an interest in cooperation. For the Germans it was important to commit as few of their own resources as possible to occupation. The Belgian municipal authorities wished to preserve

21 AVB, CB-802, Crickx to Steens, July 11, 1918; Louis Bertrand, Schaerbeek pendant la guerre 1914-1918 (Brussels, 1919), 158.

${ }^{22}$ AVB, Fonds administratif, Archives de la police, Dossiers du personnel 1916; Dossier A. E. et Dossier V. C.

${ }^{23}$ AVB, CB 802, Lemonnier, Note de février 1915 
as much as possible of the political autonomy that they had traditionally enjoyed in the Belgian political system. ${ }^{24}$ For more than a year, however, no institution coordinated cooperation between the occupier and the police forces in the sixteen communes. From the beginning, the military governor regarded all the communes as a single unit and dealt only with the council in Brussels. The Belgians themselves had contemplated administrative unification, particularly of the police, since the nineteenth century. In the view of Luc Keunings, the absence of any such centralization was in part responsible for the inefficiency of the police in Greater Brussels. ${ }^{25}$ During the war, each commune in theory retained autonomy in police matters, but Edmond Crespin, who was chief of the Central Division, became a kind of prefect of police for Greater Brussels. He could not issue direct orders to the communal forces, but he was the focus of communication between them all and the German occupier. Tendencies toward centralization were reinforced by the manner in which the German police controlled their Belgian counterparts. In November 1915, the military governor of the city of Brussels, Sauberzweig, announced the creation of a central inspectorate (Inspektionsstelle). This office worked directly under his orders, and its mission was to remain in permanent contact with all the forces responsible for keeping order in Greater Brussels. The inspectorate was composed of five officers under the leadership of a German by the name of Reichmann. From this moment on, an institutional tie was set up between occupiers and occupied for the maintenance of public order. Beginning in December 1915, when the office began its work, central control of communal police increased visibly.

Given the importance of communal autonomy, each mayor had jealously guarded his near-absolute control over the communal police, whose activities had in turn been limited to the territory of the commune. Beginning in 1916 , the Inspektionsstelle invited the police in different communes to support one another. Because the traditions of autonomy seemed stronger than anticipated, the German district chief in Brussels, von Soden, decided on September 28, 1916 to make cooperation obligatory. The mayors, as well as the police officers of the communes in question, remained alone responsible for their affairs, but they could henceforth issue orders to "outside" policemen. ${ }^{26}$ Subsequently, however, until the summer of 1917, this order had to be frequently reissued. In the second half of 1916, Reichmann instituted regular conferences among the German authorities and the sixteen commissioners of communal police. The Belgians did not have the right to develop their own policies. Consequently, centralization played out on two levels. On the one, the Germans' orders were

${ }^{24}$ Marcel van Audenhove, "L'autonomie communale," L'initiative publique des communes en Belgique 1795-1940 ( 2 vols., Brussels, 1986), 1:69-83.

${ }^{25}$ Luc Keunings, "Histoire de la police à Bruxelles (1831-1914)" (Mémoire de license, Université Libre de Bruxelles, 1980), 365.

${ }^{26}$ AVB, CB-802, Soden to 16 communes du Grand Bruxelles, September 28, 1916. uniform in all sixteen communes. Police regulations, which before the war had been the exclusive affair of each commune, were thus at least partially unified. On the other, the conferences provided occasions on which the similarities among the various communes were regularly disclosed. A great many points were discussed here, often but once, although problems that related to foodstuffs, such as the fixing of prices and the rationing of butter, were recurrent topics.

Partial centralization and enforced cooperation among the sixteen police forces represented a modernizing feature of the occupation. It occurred under the pressure of the occupier. Between 1890 and 1914, two key concepts-professionalization and centralization-had characterized the reform of the police in Imperial Germany. It was thus hardly surprising that the occupying authorities were determined to pursue a similar policy in the occupied territory, all the more because several figures in the Belgian occupation, such as Karl Gerstein from Bochum, had been directly involved in the reforming efforts in Germany. ${ }^{27}$ Under German pressure, changes that had been instituted everywhere in Europe during the previous fifty years were put at least temporarily in place in Belgium. After the war, however, the desire for communal autonomy effectively brought a return to the prewar situation.

The surveillance of the Belgian population was facilitated by a new system of controls that the German instituted. It was symbolized in the identity card. Although Belgium was one of the first countries in Europe to introduce (in 1846) a system that required the registration of all inhabitants, the German occupiers introduced their own. ${ }^{28}$ It worked along two axes, the office of registration (Meldeamt) and the identity card itself.

Offices of registration enrolled sectors of the population that the occupier regarded as particularly "dangerous." The first who were required to report, in January 1915 , were citizens of enemy states. The next group comprised Belgian males who had been born between 1892 and 1897, members of the civic guard, and German nationals who were liable for military service. Members of each group received an identity card (Meldekarte), which they were required to carry with them at all times. In addition, the communal authorities were required to submit lists of all Belgian males who had been born between 1892 and 1897 , which allowed the Germans to determine who among this military-aged cohort had not presented himself for registration. The communes were also "obligated to ensure that persons who had been registered at a 'Meldeamt' did not leave the district in which they were required to live." 29 If the commune did allow such persons to move without authorization, it was subject to a fine. The

${ }_{27}$ Stadtarchiv Bochum, ZA III B1 R, Bochumer Anzeiger, January 28, 1956; Westfälische Rundschau, January 8, 1964

${ }^{28}$ Frank Caestecker, Alien Policy in Belgium, 1840-1940: The Creation of Guest Workers, Refugees and Illegal Aliens (New York and Oxford, 2000), 6-7.

${ }_{29}$ Souvenir, 1, First Supplement: 6; ibid., 4:16-17. 
Belgian population offices were required to communicate changes in domicile to the German authorities within forty-eight hours. ${ }^{30}$ The registration of foreign nationals from states at war with Germany was made more strenuous at the end of 1915. The promise, which the Germans made several times, not to use these lists as a basis for deportations, was strongly called into question in January 1917, when persons whose names had been submitted to the Meldeämter were required to furnish special documents to prove that they had steady employment. These documents were issued by the commune. Several professions-including priests, lawyers, and intellectuals-were excluded from the requirement. That Belgian apprehension over the measure was justified was confirmed in an internal German memorandum. Its author noted that the preparation of lists of those to be deported for work in Germany had been greatly facilitated by the Meldekarten and the Belgian identity certificates. ${ }^{31}$ To allow more rapid review of categories of people who had been placed under surveillance, the cards were of several different colors-for example, gray for enemy nationals, red-brown for members of the civic guard, and green for Italians.

The second axis of control was the general introduction of the identity card. On October 30, 1915 the military governor of Brussels, Sauberzweig, announced the issuing of a "certificate of identity," which was required of "every person of every nationality over the age of fifteen." The cards were issued by the communal police. ${ }^{32}$ Control over the enforcement of Sauberzweig's order was likewise placed in their hands. At the same time, the political police devoted a significant part of their activities to this matter. In addition to descriptive details, such as the color of the eyes and hair and the shape of the nose, the identity card contained a photograph of the person. After the middle of the nineteenth century, the photograph had been increasingly used as a means of controlling marginal social groups, such as criminals or the insane. Now, however, the measure extended to the entire population. In view of the primitive state of photography in this era, the very fact of having "one's picture taken" was a novel experience for many people. ${ }^{33}$ After the war, the identity card was retained in Belgium, in order-among other things- to identify foreigners, principally the Germans who were subjected to various forms of discrimination after the liberation of Belgian territory. In the realm of legislation relating to Belgian nationality, the First World War led to a hardening of a regime that had until then been fairly liberal. ${ }^{34}$

${ }^{30}$ Ibid., 5: 113-4; 6:15

${ }^{31}$ Ibid., 17: 94; cf. BayHStA, MA 97670.

32 Bestimmungen für das Passwesen (Neudruck vom 1. April 1915). A copy is in AGR, T. 506-17, Archief van het provinciebestuur Brabant.

${ }^{33}$ Jens Jäger, Photographie: Bilder der Neuzeit. Einführung in die historische Bildforschung (Tübingen, 2000), 135-40.

${ }^{34}$ AVB, CB-802, Max note [November 1918]; AVB, CB-390, Conférence des Bourgmestres, October-November 1918.
General statistics on the wartime evolution of criminality in Brussels do not exist. The registry of one of the seven police divisions does, however, survive for the first three years of the conflict. The number of "crimes and derelictions" remained relatively stable in this period, but the number of thefts rose about a third over its prewar rate. During the first months of occupation, the German police do not seem to have been particularly concerned about this problem. They intervened only when German soldiers were directly involved. They were confronted with "everyday" criminality as they carried out their street patrols, but they did not pay much attention to it. A list of persons imprisoned in Saint-Gilles by the German police in September 1915 reveals that twelve of 125 were arrested on charges of violating Belgian laws and had had nothing to do with "politics." 35 If a German civilian committed a crime, the Belgian police were required to submit a report to the German authorities, but the case was submitted to a Belgian tribunal (until the strike in the criminaljustice system of March 1918). Beginning in 1917, however, the German forces showed an increased interest in the subject of ordinary criminality. In January the chief of the German military police ordered the police in the communes of Schaerbeek, Etterbeek, Auderghem, and Woluwe-Saint-Lambert to organize local patrols to prevent smuggling. ${ }^{36}$ From this point onward, the German intervened increasingly in the daily activities of the Brussels police. They instituted measures against peddling and theft, and they reinforced patrols along the railways. However, even at this time the German authorities focused their attentions on several critical points. These included the city's food supply, a question to which the Germans attached capital importance; but if hunger was never absent in Brussels, the situation did not deteriorate to the degree that it did in Berlin. For strategic reasons, the Germans were also intensely concerned about the railways. The same was true of theft, which affected the many German soldiers who passed through the city. At the same time, the carrying out of these measures remained in the hands of the Belgian police. The military police were never systematically deployed in the fight against ordinary criminality, not even during the war's last year, when deteriorating social and economic conditions seem to have provoked a spectacular wave of theft.

Brussels also became one of the symbols of moral decadence in the Etappe, or area immediately behind the lines. As the seat of an important bureaucracy of occupation and as a route of passage for many soldiers, the Belgian capital witnessed a great increase in the number of prostitutes during the four years of occupation. The German leadership regarded prostitution as dangerous to the physical health of the soldiers, but also as necessary to their psychological health. The Belgian authorities, on the other hand, considered it dangerous on

${ }^{35}$ AGR, T. 465-30

36 Archives de Schaerbeek, Ordre du jour de la police schaerbeekoise, No. 38, February 5,1917 . 
two levels; during the occupation their moral condemnation of it was joined by their patriotic condemnation. Because they judged them insufficient, the Germans replaced Belgian controls on prostitution in February 1915 with a system of their own, as an order from Bissing created the Sittenpolizei. This agency worked in close collaboration with Belgian police, who were detached from their local forces and integrated into the German morals police. This development represented a break in two respects. In the first place, the amalgamated morals police paid no heed whatsoever to the existence of sixteen different com munes; instead, they acted throughout Greater Brussels. As a result, communal administration not only gave up one of its basic competencies, which it had held since 1836, but it also put its own agents at the disposal of the occupier Not even during the National Socialist occupation was such a radical action undertaken. At the same time, a new regulation, which was inspired by laws in effect in Leipzig and Berlin, was instituted in Brussels. It imposed regulation of prostitutes and could be called a success. In eight months, from March through October 1915, the number of controlled prostitutes increased from 184 to 1,160 . The increase was not due alone to the rise in the number of prostitutes it was tied equally to the imposition of much more effective controls than before the war. In May 1916, nearly fifty-five percent of the women placed under medical control had venereal diseases. The first step, control by the police, was thus followed by medical control, which was also centralized throughout Greate Brussels in the Molière Hospital where, among others, the German poet Gottfried Benn worked for several years. Along with the women, their clients-German soldiers-were subjected to regular visits by health workers. The Germans' func tional approach, which involved the surveillance but not the eradication of prostitution-remained incomprehensible to the Belgian authorities, who nevertheles raised no real opposition to the German policy.

During the four years of occupation no Belgian resistance took shape com parable to that which developed during the Second World War. Nonetheless, a large majority of the Belgian population was opposed to the occupation. Many forms of "public dissent" appeared. The events that took place in connection with July 21 , the main national holiday, illustrated the potential for cooperation between the occupier and the occupied in dealing with a problem that could easily have provoked conflict. On July 21 each year, a significant part of the population participated non-violently in what was in effect a spatial reappropriation of the city. "Sites of memory," such as the Cathedral of Saints Michel and Gudule, where mass was celebrated in the afternoon, or the Martyrs' Square, which commemorated the revolution of 1830 and Belgian independence, were the principal rallying points. The military governor von Kraewe informed the public on July 18,1915 that he would not permit demonstrations. ${ }^{37}$
During the next days, fliers circulated calling for a general strike. The only altercations took place, however, when merchants refused to close their shops. ${ }^{38}$ The (1) During the military and political police remained inconspicuous on the streets. During the ensuing years, the situation changed. The orders of the German police became more precise in their prohibitions, while more detailed measures were put in effect on the Belgian side. ${ }^{39}$ In 1916, the mayor of Brussels, Maurice Lemonnier, raised no opposition to an order from Friedrich Hurt, the German military governor of Brussels, which stipulated that the command of the communal police, a basic component of the mayor's powers, be put temporarily in the hands of the military police..$^{0}$ The communal authorities, particularly those who led the communal police, themselves considered the public demonstrations a threat to public order. Accordingly, on July 13,1917, with no prompting from his superiors, a Belgian police officer proposed measures to prevent street demonstrations ${ }^{41}$ The police confiscated the fliers that circulated during the days prior to July 21. On the day itself, the commissioner of the fourth division of the police wrote to Lemonnier, not without pride, that "the attempts to stage demonstrations have been vigorously repressed."42 And several days later, Crespin, the effective chief of the Brussels police, received thanks from Vonberg, the chief of the military police: "It gives me special satisfaction to express my gratitude and appreciation to you for the peaceful way in which yesterday's events proceeded. I convey as well the gratitude of the German military police for the professional way that the police issued orders and took action."

These demonstrations were directed nevertheless at least implicitly against the Germans. On the other hand, a part of the Flemish movement, which was known as the activists, sought with the aid of the Germans to promote greater autonomy for Flanders; and this movement was ready to cooperate with the Germans. ${ }^{+4}$ Brussels, which was situated north of the linguistic frontier and had formerly been Flemish-speaking, had become a city in which French was the most common language. It consequently took on an important symbolic role in these ethnic tensions. The Flemish activists organized a significant number of meetings in the city, but they were not well attended. The police reported on every one, but their observations were limited to the number of participants and the implications for public order of what was said. That the police in Brussels rarely took action against the movement was due at least in part to

38 AVB, Division Centrale to Third Division, July 21, 1915 (Telegram No. 1134).

39 AVB, Steens, Order of July 19, 1918 (No. 1043); Kraewel, Souvenir, 12: 91

to AVB, Fonds administratif, Archives de la Police, Guerre 1914-1918 (Pol 14-18) Box 502.

41 AVB, Pol. 14-18, Box 502, Report of July 13, 1917

${ }^{42}$ Ibid., Ledoux to Lemonnier, July 21, 1917 (emphasis mine).

${ }^{43}$ Ibid., Vonberg to Crespin [July 1917]

44 Nieuwe Encyclopedie van de Vlaamse Beweging (Tielt, 1998), 205-44.

Souvenit, 5: 105-6 
the protection that the activists enjoyed from the Germans. Thus, on July 21 , 1917 several activists attempted to claim a street for their own patriotic demonstrations; public order was threatened, and the police arrested some of them Once they arrived at the police station, they were immediately released by a member of the German political police. ${ }^{45}$ Nevertheless, Flemish activism never found enough supporters in Brussels to constitute a real factor in the city's urban space.

In July 1916 Maximilian von Sandt, the head of the Zivilverwaltung, wrote to Berlin that "the well developed communal self-administration has ... proved its worth in maintaining law and order." 46 This conclusion was still valid two years later, when the last German soldiers left Brussels in November 1918. During the four years of occupation, the population of the city was never a destabilizing factor in the German war effort. As a result, German troops did not have to be stationed in the city to control unrest, nor were the railways ever seriously disrupted.

From the beginning of the occupation, the organization of both the Belgian and German police was chaotic. On the Belgian side, only the communal police remained in place, but they lost many of their leading officers. Unlike other facets of the Belgian administration, however, no one in the police bureaucracywhether communal authorities or ordinary policemen-thought of stopping work. On the German side, no measures had been prepared for an extended occupation of Belgium. A coherent police system was put in place only several months into the war.

On the Belgian side, the war seemed to bring a decline in both the quantity and quality of the forces available to maintain order in Brussels. The army and the gendarmerie left the capital, while the communal police lost many men, not all of whom could be replaced. Moreover, the new ones who were hired were less qualified for police work. Still, the presence of the Germans promoted the extensive modernization of the communal police. Command was more or less consolidated in the person of Crespin and a central agency, the Inspektionsstelle. Regular conferences took place to promote coordination and day-to-day cooperation among the sixteen communal police forces. The polycratic structure of the German administration posed its own problems, but it does not appear to have led to contradictory orders to the police. The division of labor was clear; the governor-general had authority over three police agencies, which in turn had competence in three well defined areas. In this war, unlike the next, the Germans did not ask the Belgian police to counteract political agitation directly. The communal police forces dealt with most of the police work themselves. Within this framework, however, they supported the Germans' goals-

${ }_{45}$ AVB, Pol. 14-18, Box 528, Report of July 22, 1917 from the Fourth Division.

${ }^{46}$ BarchB, R1501-19456, Verwaltungsbericht des Verwaltungschefs bei dem General gouverneur in Belgien für das Halbjahr Februar-Juli 1916. either directly, by maintaining order during "patriotic" demonstrations, or indirectly, by facilitating control of the population. The cooperation of the Belgian police with the occupier was nowhere more extensive than in the area of prostitution. But in spite of frequent conflicts between the Germans and a succession of mayors in Brussels, the maintenance of order never reached the point of rupture. 